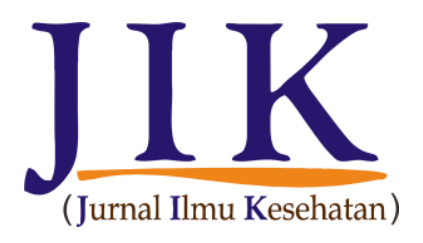

JIK (Jurnal Ilmu Kesehatan)

Online ISSN: 2597-8594

Print ISSN: 2580-930X

Jurnal homepage: https://jik.stikesalifah.ac.id

\title{
Faktor Yang Berhubungan Dengan Pelaksanaan Universal Precautions Di Instalasi Gawat Darurat
}

\author{
Tiurmaida Simandalahi ${ }^{1}$, Andika Herlina Marda Prawata ${ }^{2}$, Elisabeth Novita Angriani L.Toruan ${ }^{3}$ \\ ${ }^{1,2}$ Prodi Keperawatan \& Ners, STIKes Syedza Saintika, Padang, Indonesia, 25173 \\ Email: tiurmaidamandalahi@gmail.com \\ ${ }^{3}$ Prodi D3 Ilmu Keperawatan, Akademi Keperawatan Pemkab, Tapanuli Utara, Indonesia, 22411 \\ Email: elisabeth.lumbantoruan@gmail.com
}

\begin{abstract}
Abstrak
Petugas pelayanan kesehatan terutama perawat sering terpajan mikroorganisme yang dapat menyebabkan infeksi serius atau bahkan mematikan. Untuk melindungi perawat dan pasien dari resiko tertular penyakit infeksi maka perawat harus selalu memperhatikan pelaksanaan universal precautions. Tujuan penelitian adalah untuk mengetahui faktor-faktor yang berhubungan dengan pelaksanaan universal precautions di RSU Kerinci. Jenis penelitian: deskriptif analitik dengan desain cross sectional study, Penelitian dilaksanakan Juni-Juli 2018, dengan populasi semua perawat di Instalasi Gawat Darurat RSU Kerinci berjumlah 32 orang perawat yang diambil dengan teknik Total Population. Data diolah secara komputerisasi, dianalisis secara univariat dan bivariat dengan Uji Chi-Square dengan tingkat kemaknaan 0,5\%. Hasil penelitian didapatkan 53,1\% responden melaksanakan universal precaution, tingkat pengetahuan tinggi $(68,8 \%)$, sikap positif (53,1\%), 50\% responden tidak pernah mengikuti pelatihan, 59,4\% responden menyatakan sarana dan prasarana mendukung. Hasil uji Chi-Square didapatkan hubungan tingkat pengetahuan ( $p$-value $=0,002)$, sikap $(p$-value $=0,014)$, pelatihan $(p$-value $=0,005)$ dan sarana dan prasarana $(p$-value $=0,001)$ yang berhubungan dengan pelaksanaan Universal Precaution. Disimpulkan bahwa tingkat pengetahuan, sikap, pelatihan dan sarana dan prasarana sangat mendukung pelaksanaan Universal Precaution.
\end{abstract}

Kata kunci: Universal Precaution, Pengetahuan, Sikap, Pelatihan, Sarana dan Prasarana

\section{Factors Related To The Implementation of Universal Precautions in Emergency Installation}

\begin{abstract}
Health care workers, especially nurses have often exposed to microorganisms, which can cause serious or even deadly infections. To protect nurses and patients from the risk of contracting the infection, the nurse must always pay attention to the universal precautions. The purpose of this study was to determine the factors related to the implementation of universal precautions at the Emergency Installation of Kerinci Hospital. This research is descriptive-analytic with a cross-sectional study design, conducted from June - July 2018, with the population being all nurses at the Emergency Department of Kerinci Hospital with a total of 32 nurses taken using the total population technique. Data were analyzed computerized, with univariate and bivariate using Chi-Square Test.The results showed that 53,1\% respondents carried out universal precaution, high level of knowledge (68.8\%), positive attitude (53.1\%), 50.0\% never attended training, 59.4\% stated that precaution universal infrastructure and facilities support. The results of Chi-Square test showed that there was a correlation between the level of knowledge ( $p$-value $=0.002)$, attitude ( $p$-value $=0.014)$, training ( $p$ value $=0.005)$ and facilities and infrastructure $(p$-value $=0.001)$ with the implementation of Universal Precaution. It has concluded that the level of knowledge, attitude, training and facilities and infrastructure strongly supports the implementation of Universal Precaution.
\end{abstract}

Keywords: Universal Precaution, Knowledge, Attitudes, Training, Facilities and Infrastructure 


\section{PENDAHULUAN}

Kejadian penyakit infeksi di pusat pelayanan kesehatan dianggap sebagai suatu masalah serius karena mengancam kesehatan dan keselamatan pasien dan petugas kesehatan secara global (Luo, Y., He, G.P., Zhou, J.W., \& Ying, L, 2010).

Sahara (2011) menyatakan bahwa perawat dalam menjalankan tugasnya dituntut untuk memiliki pengetahuan dan keterampilan yang kompeten dibidangnya karena resiko pekerjaan perawat tidak hanya menyangkut kesehatan dan keselamatan pasien tetapi juga menyangkut kesehatan dan keselamatan perawat. Salah satu resiko serius tersebut adalah tertular atau menularkan penyakit Infeksi (Sahara, 2011).

Resiko tertular atau menularkan penyakit infeksi seperti blood borne:HIV, Hepatitis B dan Hepatitis C, berasal dari sumber infeksi yang diketahui atau yang tidak diketahui seperti benda terkontaminasi, jarum suntik bekas pakai dan benda tajam lainnya. Secara global, lebih dari 35 juta petugas kesehatan menghadapi resiko luka perkutan akibat terkena benda tajam yang terkontaminasi. Insiden terpapar mikroorganisme yang diobservasi diantara semua petugas kesehatan yang paling tinggi terpajan adalam perawat (Efstathiou, 2011).

Menurut World Health Organization (WHO) pada tahun 2002, telah terjadi lebih dari 16.000 kasus penularan virus Hepatitis C, 66.000 kasus penularan Hepatitis B dan 1000 kasus penularan HIV pada tenaga kesehatan diseluruh dunia (Syahrizal, I., Darwin, K., \& Fathra, A, 2015).

National Safety Council (NSC) dalam Permenkes RI, (2010) melaporkan kecelakaan di Rumah Sakit, 41\% lebih besar daripada kecelakaan di industri. Kasus kecelakaan tersering adalah tertusuk jarum, terkilir, sakit pinggang, tergores/terpotong, luka bakar, dan penyakit infeksi lainnya.

Penelitian lain dilakukan di RSUD Kabupaten Cianjur menyebutkan bahwa jumlah perawat yang mengalami luka tusuk jarum dan benda tajam lainnya adalah cukup tinggi yaitu sebanyak 61,34\% (Hermana, 2009).

Untuk melindungi perawat dan pasien dari resiko tertular penyakit infeksi tersebut maka dalam melaksanakan tindakan keperawatan, perawat harus selalu memperhatikan metode universal precautions (Kewaspadaan Universal) yang telah ditetapkan oleh Centers for Disease Control And Prevention (CDC) pada tahun 1988 di Amerika Serikat (Kirkland, 2011).

Universal precautions adalah suatu tindakan pengendalian infeksi yang dilakukan oleh seluruh tenaga kesehatan untuk mengurangi resiko penyebaran infeksi dengan didasarkan pada prinsip bahwa darah dan cairan tubuh dapat berpotensi menularkan penyakit, baik berasal dari pasien maupun petugas kesehatan (Nursalam, 2007).

Penerapan universal precautions harus menjadi perhatian dan dilaksanakan oleh perawat yang ada diseluruh rumah sakit di Indonesia. Sebagaimana yang telah ditetapkan oleh Depkes RI melalui Keputusan Menteri Kesehatan RI (Kepmenkes RI) Nomor: 382/menkes/SK/III/2007 tentang Pedoman Pencegahan dan Pengendalian Infeksi dirumah sakit dan fasilitas pelayanan kesehatan lainnya. Tetapi pada kenyataannya, dari hasil survei yang dilakukan oleh Depkes RI dan WHO ke rumah sakit-rumah sakit di propinsi dan kabupaten/kota di Indonesia masih banyak rumah sakit daerah yang belum menjalankan pedoman pencegahan dan pengendalian infeksi dengan metode universal precautions tersebut (Departemen Kesehatan, R.I, 2009).

Permasalahan kepatuhan penerapan kewaspadaan standar di Indonesia disebabkan oleh keterbatasan fasilitas dalam pengendalian infeksi, misalnya fasilitas cuci tangan hanya sedikit yang tersedia dan jika tersedia kadangkadang tanpa sabun dan handuk. Terkadang ketersediaan air mengalir juga tidak tersedia. Selain itu, pembersih tangan yang berbasis alkohol tidak tersedia secara luas dan sering kekurangan sarung tangan, gaun dan masker (Duerink, O., Farida, H., Nagelkerke, N., et al, 2006). Beberapa perawat mengatakan tidak melakukan perlindungan diri disebabkan karena sarana yang kurang seperti sarung tangan tidak cukup, sabun cuci tangan habis, hal ini menunjukkan ketersediaan sarana dan prasarana sangat mempengaruhi perawat dalam pelaksanaan universal precautions (Efstathiou, 2011). 
Hasil penelitian Krisnata (2016) yang berjudul faktor-faktor yang berhubungan dengan praktik universal precautions pada perawat dalam upaya pencegahan risiko healthcare associated infections (HAIs) di Ruang Rawat Inap RSUD Tugurejo Semarang didapatkan hasil bahwa faktor yang berhubungan dengan praktik universal precautions perawat adalah pengetahuan tentang infeksi nosokomial dan upaya pencegahan $(\mathrm{p}=0,014)$, supervisi kepala ruang $(\mathrm{p}=0,045)$, dukungan sejawat $(\mathrm{p}=0,023)$, pelatihan pencegahan dan pengendalian infeksi $(\mathrm{p}=0,001)$, dan ketersediaan sarana dan prasarana $(\mathrm{p}=0,018)($ Krisnata, 2016).

Hasil observasi yang dilakukan oleh peneliti dengan perawat di salah satu IGD rumah sakit umum Kerinci pada tanggal 9-10 Juni 2018 masih banyak petugas kesehatan terutama perawat yang tidak mengindahkan dan memperhatikan metode universal precautions dalam melaksanakan tindakan keperawatan, peneliti melihat perawat tidak menggunakan sarung tangan dan masker setiap melakukan pengkajian, khususnya sarung tangan hanya digunakan beberapa perawat saja. Mencuci tangan dengan teknik aseptikpun jarang dilakukan. Kalaupun dilakukan tidak dengan teknik yang tepat, semua perawat tersebut tidak pernah mendapatkan pelatihan khusus membahas tentang universal precautions. Hanya mendapatkan informasi tentang universal precautions saat menjalani pendidikan. Sarana dan prasarana universal precautions di Instalasi Gawat Darurat RSU Kerinci seperti wastafle tempat cuci tangan yang kurang, peralatan cuci tangan yang kurang memadai.

Tujuan penelitian ini adalah untuk mengetahui faktor-faktor yang berhubungan dengan pelaksanaan universal precautions di Instalasi Gawat Darurat RSU Kerinci Tahun 2018.

\section{METODE PENELITIAN}

Penelitian ini merupakan penelitian deskriptif analitik dengan desain cross sectional. Populasi dalam penelitian ini adalah semua perawat yang berada di Instalasi Gawat Darurat RSU Kerinci yang berjumlah sebanyak 32 orang. Sampel dalam penelitian ini diambil secara Total Populasi. Penelitian ini dilakukan dilakukan di Instalasi Gawat Darurat RSU Kerinci.

Alat pengukuran data menggunakan kuesioner. Penelitian ini terdiri dari kuesioner pelaksanaan universal precautions, pengetahuan, sikap, pelatihan, sarana dan prasarana. Analisis data yang digunakan dalam penelitian ini adalah analisis univariat dan bivariat dengan uji Chi-Square.

\section{HASIL DAN PEMBAHASAN}

\section{Tabel 1}

Distribusi Frekuensi Karakteristik Responden

\begin{tabular}{|c|c|c|c|}
\hline No & $\begin{array}{c}\text { Karakteristik } \\
\text { Responden }\end{array}$ & f & $\%$ \\
\hline \multirow[t]{3}{*}{1} & Umur & & \\
\hline & $<30$ tahun & 22 & 68,8 \\
\hline & b. $\geq 30$ tahun & 10 & 31,2 \\
\hline \multirow[t]{3}{*}{2} & Jenis Kelamin & & \\
\hline & a. Perempuan & 19 & 59,4 \\
\hline & b. Laki-laki & 13 & 40,6 \\
\hline \multirow[t]{3}{*}{3} & Tingkat Pendidikan & & \\
\hline & a. D3 (Vokasional) & 22 & 68,8 \\
\hline & b. S1 (Profesional) & 10 & 31,2 \\
\hline \multirow[t]{3}{*}{4} & Masa Kerja & & \\
\hline & a. $<5$ tahun & 0 & 0 \\
\hline & b. $\geq 5$ tahun & 32 & 100 \\
\hline
\end{tabular}

Tabel 1 menunjukkan bahwa dari 32 responden lebih dari separuh $(68,8 \%)$ berumur $<30$ tahun, lebih dari separuh $(59,4 \%)$ berjenis kelamin perempuan, lebih dari separuh $(68,8 \%)$ berpendidikan D3 Keperawatan, dan 100\% responden dengan masa kerja $\geq 5$ tahun.

Tabel 2

Distribusi Frekuensi Pelaksanaan Universal Precaution, Tingkat Pengetahuan, Sikap, Pelatihan dan Sarana dan Prasarana

\begin{tabular}{|c|c|c|c|}
\hline $\begin{array}{l}\mathbf{N} \\
\mathbf{0}\end{array}$ & Variabel & $\mathbf{F}$ & $\%$ \\
\hline \multirow[t]{4}{*}{1.} & $\begin{array}{l}\text { Pelaksanaan Universal } \\
\text { Precaution }\end{array}$ & & \\
\hline & a. Tidak Dilaksanakan & 15 & 46,9 \\
\hline & b. Dilaksanakan & 17 & 53,1 \\
\hline & Tingkat Pengetahuan & & \\
\hline \multirow[t]{3}{*}{2.} & a. Rendah & 10 & 31,2 \\
\hline & b. Tinggi & 22 & 68,8 \\
\hline & Sikap & & \\
\hline \multirow[t]{3}{*}{3.} & a. Negatif & 15 & 46,9 \\
\hline & b. Positif & 17 & 53,1 \\
\hline & Pelatihan & & \\
\hline \multirow[t]{3}{*}{4.} & a. Tidak Pernah & 16 & 50,0 \\
\hline & b. Pernah & 16 & 50,0 \\
\hline & Sarana dan Prasarana & & \\
\hline \multirow[t]{2}{*}{5.} & a. Tidak Mendukung & 13 & 40,6 \\
\hline & b. Mendukung & 19 & 59,4 \\
\hline
\end{tabular}


Tabel 2 menunjukkan bahwa lebih dari separuh responden $(53,1 \%)$ melaksanakan universal precaution. Lebih dari separuh $(68,8 \%)$ tingkat pengetahuannya tinggi. Lebih dari separuh $(53,1 \%)$ sikapnya positif. Dalam mengikuti pelatihan, sebagian $(50,0 \%)$ perawat pernah mengikuti pelatihan universal precaution dan sebagian lagi $(50,0 \%)$ tidak pernah mengikuti pelatihan universal precaution. Lebih dari separuh $(59,4 \%)$ menyatakan sarana dan prasarana mendukung.

Kewaspadaan universal merupakan suatu tindakan pengendalian infeksi yang dilakukan oleh seluruh tenaga kesehatan untuk mengurangi risiko penyebaran infeksi dan didasarkan pada prinsip bahwa darah dan cairan tubuh dapat berpotensi menularkan penyakit, baik berasal dari pasien maupun petugas kesehatan (Nursalam, 2007). Tindakan yang dapat mengakibatkan luka atau tumpahan cairan tubuh, atau penggunaan alat medis yang tidak steril, dapat menjadi sumber infeksi penyakit tersebut pada petugas layanan kesehatan dan pasien lain. Prosedur universal precautions bertujuan untuk melindungi petugas kesehatan, pasien dan staf dari paparan objek yang infeksius selama porsedur perawatan berlangsung (Krisnata, 2016).

Menurut analisa peneliti, lebih dari separuh responden yang melaksanaan universal precaution disebabkan adanya perawat yang selalu melakukan cuci tangan setiap sebelum dan sesudah melakukan tindakan, mencuci tangan dengan menggunakan larutan antiseptik, adanya perawat yang selalu memakai alat pelindung diri seperti sarung tangan dan masker, adanya perawat yang selalu membuang benda tajam ke dalam kontainer khusus, melakukan pembuangan sampah medis ke

\section{Tabel 3}

Hubungan Tingkat Pengetahuan dengan Pelaksanaan Universal Precaution

\begin{tabular}{|c|c|c|c|c|c|c|c|c|}
\hline \multirow{3}{*}{$\begin{array}{c}\text { Tingkat } \\
\text { Pengetahuan }\end{array}$} & \multicolumn{4}{|c|}{ Pelaksanaan Universal Precaution } & \multirow{2}{*}{\multicolumn{2}{|c|}{ Jumlah }} & \multirow{3}{*}{ p-value } & \multirow{3}{*}{ OR $(95 \% \mathrm{CI})$} \\
\hline & \multicolumn{2}{|c|}{ Tidak Dilaksanakan } & \multicolumn{2}{|c|}{ Dilaksanakan } & & & & \\
\hline & f & $\%$ & $\mathbf{F}$ & $\%$ & $\mathbf{F}$ & $\%$ & & \\
\hline Rendah & 9 & 90,0 & 1 & 10,0 & 10 & 100 & \multirow{3}{*}{0,002} & \multirow{3}{*}{$\begin{array}{c}24.000(2.482- \\
232.087)\end{array}$} \\
\hline Tinggi & 6 & 27,3 & 16 & 72,7 & 22 & 100 & & \\
\hline Jumlah & 15 & 46,9 & 17 & 53,1 & 32 & 100 & & \\
\hline
\end{tabular}

Tabel 3 menunjukkan responden yang tidak melaksanakan universal precaution ditemukan pada perawat yang memiliki pengetahuan rendah yaitu 9 responden $(90,0 \%)$, tempat yang terpisah sesuai dengan label atau kode warnanya.

Sedangkan masih ada perawat yang tidak melaksanakan universal precaution disebabkan oleh adanya perawat yang tidak mencuci tangan sebelum dan sesudah menggunakan sarung tangan, masih ada perawat yang hanya mencuci tangan saja tanpa menggunakan sabun atau deterjen, masih ada perawat yang tidak menggunakan alat pelindung diri seperti kaca mata khusus, celemek dan sepatu saat melakukan tindakan yang kemungkinan dapat terkena cipratan cairan tubuh seperti darah, masih ada perawat yang tidak melakukan dekontaminasi alat kesehatan.

Hal ini didukung oleh analisa peneliti terhadap jawaban responden tentang pelaksanaan universal precaution, 40,6\% perawat yang menyatakan kadang-kadang ada melakukan cuci tangan sebelum memakai sarung tangan, 18,8\% menyatakan jarang melakukan cuci tangan sebelum memakai sarung tangan. Didapatkan bahwa 53,1\% perawat menyatakan kadang-kadang mencuci tangan setelah memakai sarung tangan, 15,6\% menyatakan jarang mencuci tangan setelah memakai sarung tangan, 43,8\% menyatakan memakai masker, $28,1 \%$ jarang memakai masker, $21,9 \%$ menyatakan kadang-kadang memakai kacamata melindung, 28,1\% jarang memakai kacamata pelindung, 43,8\% menyatakan kadang-kadang memakai sepatu pelindung, 9,38\% jarang memakai sepatu pelindung, $28,1 \%$ menyatakan jarang melakukan dekontaminasi pada alat kesehatan bekas pakai. Berdasarkan hal tersebut dapat diambil kesimpulan bahwa 46,9\% responden tidak melaksanakan universal precaution berdasarkan jawaban kuesioner dari responden. pengetahuan tinggi yaitu 6 responden $(27,3 \%)$ dengan hasil uji statistik diperoleh nilai $\mathrm{p}=$ $0,002(<0,05)$ yang berarti $\mathrm{H}_{0}$ ditolak sehingga 
disimpulkan ada hubungan yang signifikan antara tingkat pengetahuan dengan pelaksanaan universal precaution.

\section{Menurut Notoatmodjo} pengetahuan bisa didapatkan dengan cara formal dan informal. Pengalaman merupakan salah satu faktor dari terbentuknya pengetahuan. Pengalaman belajar dalam bekerja yang dikembangkan memberikan pengetahuan dan keterampilan profesional serta pengalaman belajar akan dapat mengembangkan kemampuan mengambil keputusan yang merupakan manifestasi dari keterpaduan menalar secara ilmiah dan etik yang bertolak dari masalah nyata dalam bidang keperawatan. Pendidikan juga merupakan faktor yang mendukung. Pengetahuan dapat diukur dengan tingkatan yaitu tingkat pengetahuan rendah dan tingkat pengetahuan tinggi (Notoatmodjo, 2011).

Menurut analisa peneliti, lebih dari separuh responden yang memiliki tingkat pengetahuan tinggi disebabkan karena sebagian besar perawat sudah memiliki pengetahuan yang baik yang diperoleh dari pelatihan dan berbagi ilmu dengan teman sejawat maupun dari atasan. Sedangkan masih ada perawat yang memiliki pengetahuan rendah disebabkan pendidikan yang masih D3 Keperawatan yang disertai dengan kurangnya pengalaman dalam pelatihan tentang universal precaution dan juga kurang mendapatkan ilmu dan informasi dari teman sejawat.

Hal ini didukung oleh analisa peneliti terhadap jawaban responden terhadap pertanyaan tentang pengetahuan pelaksanaan universal precaution, $50 \%$ responden yang menjawab tidak tahu tentang cara menutup jarum suntik dengan teknik satu tangan (recapping), 40,6\% responden yang salah menjawab tentang cara menangani jarum infus yang telah terkontaminasi dengan aman, 31,3\% responden yang salah menjawab kapan kewaspadaan standar dilaksanakan, kapan sebaiknya cuci tangan saat kontak dengan darah/cairan tubuh pasien, urutan pemrosesan alat medis tercemar darah/cairan tubuh, dan proses pengolahan limbah medis.

Tabel 4

Hubungan Sikap dengan dengan Pelaksanaan Universal Precaution

\begin{tabular}{|c|c|c|c|c|c|c|c|c|}
\hline \multirow{3}{*}{ Sikap } & \multicolumn{4}{|c|}{ Pelaksanaan Universal Precaution } & & & \multirow{3}{*}{$\begin{array}{c}\text { p- } \\
\text { value }\end{array}$} & \multirow{3}{*}{$\begin{array}{c}\text { OR } \\
(95 \% \mathrm{CI})\end{array}$} \\
\hline & \multicolumn{2}{|c|}{ Dilaksanakan } & \multicolumn{2}{|c|}{ Dilaksanakan } & \multicolumn{2}{|c|}{ Jumlah } & & \\
\hline & $\mathbf{F}$ & $\%$ & $\mathbf{F}$ & $\%$ & $\mathbf{F}$ & $\%$ & & \\
\hline Negatif & 11 & 73,3 & 4 & 26,7 & 15 & 100 & & \\
\hline Positif & 4 & 23,5 & 13 & 76,5 & 17 & 100 & 0,014 & $\begin{array}{c}8.938(1.801- \\
44343)\end{array}$ \\
\hline Jumlah & 15 & 46,9 & 17 & 53,1 & 32 & 100 & & \\
\hline
\end{tabular}

Tabel 4 terlihat bahwa responden yang dipersepsi berbeda-beda oleh setiap orang dan tidak melaksanakan universal precaution ditemukan pada perawat yang memiliki sikap negatif yaitu 11 responden $(73,3 \%)$, dibandingkan dengan perawat yang memiliki sikap positif yaitu 4 responden $(23,5 \%)$, dengan hasil uji statistik diperoleh nilai $\mathrm{p}=0,014$ (< $0,05)$ berarti $\mathrm{H}_{0}$ ditolak, sehingga disimpulkan ada hubungan yang signifikan antara sikap dengan pelaksanaan universal precautions.

Hasil penelitian ini sama dengan hasil penelitian Iswanti (2017) yang berjudul analisis faktor yang mempengaruhi pelaksanaan universal precaution menyatakan lebih dari separuh responden memiliki sikap positif $(85,5 \%)$.

Menurut Aswar, sikap merupakan kondisi sulit diukur karena sangat personal, sangat tertutup. Tuhan menciptakan manusia dengan segala kelebihan dan kekurangan baik laki-laki maupun perempuan. Sikap belum merupakan tindakan atau aktivitas akan tetapi merupakan suatu disposisi tindakan atau perilaku. Sikap itu masih merupakan reaksi tertutup bukan reaksi terbuka atau tingkah laku terbuka (Notoatmojo, 2011)

Menurut analisa peneliti, beberapa perawat sudah ada yang memiliki persepsi bahwa pelaksanaan universal precaution sangat penting untuk melindungi petugas kesehatan, pasien dan staf dari paparan objek yang infeksius selama porsedur perawatan berlangsung. Sehingga perawat benar-benar termotivasi untuk melakukan pelaksanaan universal precaution dengan baik kepada pasiennya. Sedangkan perawat yang memiliki sikap negatif 
dikarenakan masih memiliki persepsi yang salah mengenai pentingnya universal precaution bagi pasiennya sehingga akan menimbulkan sikap yang kurang peduli terhadap pelaksanaan universal precaution.

Sesuai dengan analisis jawaban responden terhadap pernyataan sikap, 60,87\% responden yang menyatakan setuju cuci tangan tidak terlalu penting jika akan menggunakan sarung tangan, $60,87 \%$ responden yang menyatakan setuju perawat tidak perlu terlalu khawatir setelah satu kali tusukan jarum tidak akan tertular penyakit, 53,12\% responden yang menyatakan tidak setuju selalu memperhatikan tempat penampungan jarum suntik yang kedap air, tidak mudah bocor dan tahan tusukan.

Tabel 5

Hubungan Pelatihan dengan dengan Pelaksanaan Universal Precaution

\begin{tabular}{|c|c|c|c|c|c|c|c|c|}
\hline \multirow{3}{*}{ Pelatihan } & \multicolumn{4}{|c|}{ Pelaksanaan Universal Precaution } & \multirow{2}{*}{\multicolumn{2}{|c|}{ Jumlah }} & \multirow{3}{*}{ p-value } & \multirow{3}{*}{$\begin{array}{c}\text { OR } \\
(95 \% \mathrm{CI})\end{array}$} \\
\hline & \multicolumn{2}{|c|}{ Tidak Dilaksanakan } & \multicolumn{2}{|c|}{ Dilaksanakan } & & & & \\
\hline & $\mathbf{F}$ & $\%$ & f & $\%$ & f & $\%$ & & \\
\hline Tidak Pernah & 12 & 75,0 & 4 & 25,0 & 16 & 100 & \multirow{3}{*}{0,005} & \multirow{3}{*}{$\begin{array}{c}13.000(2.398 \\
70.461)\end{array}$} \\
\hline Pernah & 3 & 18,8 & 13 & 81,2 & 16 & 100 & & \\
\hline Jumlah & 15 & 46,9 & 17 & 53,1 & 32 & 100 & & \\
\hline
\end{tabular}

Tabel 5 terlihat bahwa responden yang tidak melaksanakan universal precaution ditemukan pada perawat yang tidak pernah mendapatkan pelatihan yaitu 12 responden (75,0\%), dibandingkan perawat yang pernah mendapatkan pelatihan yaitu 3 responden $(18,8 \%)$, dengan hasil uji statistik nilai $p=0,005$ (< 0,05$)$ yang berarti $\mathrm{H}_{0}$ ditolak sehingga disimpulkan ada hubungan yang signifikan antara pelatihan dengan pelaksanaan universal precaution.

Sebanyak $50 \%$ perawat tidak pernah mengikuti pelatihan universal precaution, dan $50 \%$ pernah mengikuti pelatihan. Sejalan dengan penelitian Angelia, et al (2016) bahwa separuh responden mendapatkan pelatihan dengan baik (50\%) (Angelia, M.L., Wagey, F,. Tumurang, M, 2016).

\section{Tabel 6}

Hubungan Sarana dan Prasarana dengan dengan Pelaksanaan Universal Precaution

\begin{tabular}{|c|c|c|c|c|c|c|c|c|}
\hline \multirow{4}{*}{$\begin{array}{c}\text { Sarana dan } \\
\text { Prasarana }\end{array}$} & \multicolumn{6}{|c|}{ Pelaksanaan Universal Precaution } & \multirow{4}{*}{ p-value } & \multirow{4}{*}{$\begin{array}{c}\text { OR }(95 \% \\
\text { CI })\end{array}$} \\
\hline & \multirow{2}{*}{\multicolumn{2}{|c|}{ Tidak Dilaksanakan }} & \multirow{2}{*}{\multicolumn{2}{|c|}{ Dilaksanakan }} & \multicolumn{2}{|c|}{ Jumlah } & & \\
\hline & & & & & & & & \\
\hline & $\mathbf{f}$ & $\%$ & $\mathbf{F}$ & $\%$ & f & $\%$ & & \\
\hline Tidak Mendukung & 11 & 84,6 & 2 & 15,4 & 13 & 100 & & 20.625 \\
\hline Mendukung & 4 & 21,1 & 15 & 78,9 & 19 & 100 & 0,001 & (3.188- \\
\hline Jumlah & 15 & 46,9 & 17 & 53,1 & 32 & 100 & & 133.446) \\
\hline
\end{tabular}

Tabel 6 terlihat bahwa responden yang dibandingkan sarana yang mendukung sebanyak tidak melaksanakan universal precaution dikarenakan sarana dan prasarana tidak mendukung yaitu 11 responden $(84,6 \%)$, 4 responden $(21,1 \%)$, dengan hasil uji statistik nilai $\mathrm{p}=0,001(<0,05)$ yang berarti $\mathrm{H}_{0}$ ditolak sehingga ada hubungan yang signifikan antara 
sarana dan prasarana dengan pelaksanaan universal precaution.

Menurut Dirjen P2 MPL (2010) sumber daya yang dibutuhkan petugas kesehatan dalam menerapkan pencegahan dan pengendalian infeksi di tempat kerja yaitu tersedianya sarana dan prasarana cuci tangan, Alat Pelindung Diri (APD), perlengkapan disinfektan dan sterilisasi, serta perlengkapan untuk pengelolaan benda tajam dan pembuangan limbah baik medis maupun non medis (Krisnata, 2016).

Menurut analisa peneliti, sebagian besar sarana dan prasarana dalam pelaksanaan universal precaution sudah tersedia seperti washtafle, air mengalir, sarung tangan, tempat pencucian alat kesehatan, alat sterilisasi, wadah penampungan benda tajam, tempat sampah sesuai kode warna dan tempat pembuangan akhir, namun ada beberapa sarana dan prasarana yang ketersediaannya tidak memadai atau tidak mencukupi, sehingga perawat terkadang menggunakan, dan terkadang juga tidak menggunakannya seperti ketersediaan sarung tangan steril, sarung tangan bersih yang kadang habis, pelindung wajah, kacamata, pelindung kepala, celemek, sepatu pelindung yang ketersediaannya terbatas. Terkadang perawat juga melihat jenis kasus yang didahapinya, jika kasus pasien non infeksius, perawat terkadang tidak menggunakan handscoon agar tindakan lebih cepat dan nyaman seperti saat memasang infus, mengukur tanda-tanda vital pasien, dan lain-lainnya.

\section{Hubungan Tingkat Pengetahuan, Sikap, Pelatihan, Sarana dan Prasarana dengan Pelaksanaan Universal Precaution}

Tabel 3 menunjukkan responden yang tidak melaksanakan universal precaution ditemukan pada perawat yang memiliki pengetahuan rendah yaitu 9 responden $(90,0 \%)$, dibandingkan dengan perawat yang memiliki pengetahuan tinggi yaitu 6 responden $(27,3 \%)$ dengan hasil uji statistik diperoleh nilai $\mathrm{p}=$ $0,002(<0,05)$ yang berarti $\mathrm{H}_{0}$ ditolak sehingga disimpulkan ada hubungan yang signifikan antara tingkat pengetahuan dengan pelaksanaan universal precaution.

Hasil penelitian ini sejalan dengan hasil penelitian Krisnata (2016) dimana faktor yang berhubungan dengan praktik universal precautions perawat adalah pengetahuan tentang infeksi nosokomial dan upaya pencegahan ( $p$ value $=0,014$ )

Pengetahuan dan pengalaman dalam bekerja dapat membuat seseorang menjadi terampil karena tindakan tersebut sering dilakukan secara berulang dan secara terus menerus. Dengan mempunyai pengetahuan seseorang akan semakin mampu dalam menangani dan memecahkan suatu permasalahan yang kompleks, dimana seseorang tersebut akan mencoba mempraktekkan materi yang telah diterima. Dengan sering mengulangi secara teratur dan konsisten dapat timbul suatu keterampilan baru yang menjadikan seseorang itu terampil. Sehingga semakin banyak seseorang mempunyai pengetahuan serta sering dilatih secara berulang dan terus menerus akan menjadikan pelaksanaan tindakan yang tepat (Nurkolis \& Alimansur, 2013).

Menurut analisa peneliti, responden yang pengetahuannya rendah tetapi melaksanakan universal precaution hal ini disebabkan karena perawat mendapatkan dukungan dari teman sejawat atau dari atasan untuk melakukan universal precaution dan perawat juga melihat teman sejawatnya melakukan universal precaution sehingga mereka mengikuti yang dilakukan teman sejawatnya. Kurangnya ilmu yang dimiliki tentang pelaksanakan universal precaution sehingga keinginan untuk melakukan universal precaution kepada pasien terhambat karena ketakutan atas ketidaktahuan mereka tentang keuntungan dan kerugian pelaksanaan universal precaution untuk diri sendiri dan pasien.

Responden yang memiliki tingkat pengetahuan tinggi dan melaksanakan universal precaution disebabkan karena responden yang memiliki tingkat pengetahuan tinggi yang diperoleh dari pendidikan maupun pelatihan serta berbagi ilmu dengan teman sejawat maupun dari atasan sehingga perawat tersebut mengerti dan paham akan pentingnya melaksanakan universal precaution bagi perawat dan pasien. Responden yang pengetahuannya tinggi tetapi tidak melaksanakan universal precaution menurut peneliti hal ini dipengaruhi oleh ketidakpedulian perawat terhadap pelaksanaan universal precaution pada pasiennya.

Tabel 4 terlihat bahwa responden yang tidak melaksanakan universal precaution 
ditemukan pada perawat yang memiliki sikap negatif yaitu 11 responden (73,3\%), dibandingkan dengan perawat yang memiliki sikap positif yaitu 4 responden $(23,5 \%)$, dengan hasil uji statistik diperoleh nilai $\mathrm{p}=0,014$ (< $0,05)$ berarti $\mathrm{H}_{0}$ ditolak, sehingga disimpulkan ada hubungan yang signifikan antara sikap dengan pelaksanaan universal precautions.

Hasil penelitian ini tidak sama dengan hasil penelitian Iswanti (2017) yang menyatakan tidak ada hubungan variabel sikap dengan pelaksanaan universal precaution ( $p$-value $=0,491$ ).

Faktor predisposisi yang mempengaruhi perilaku seseorang terhadang kesehatan adalah pengetahuan, sikap, keyakinan, kepercayaan dan nilai-nilai. Sikap merupakan reaksi atau respon yang masih tertutup pada seseorang terhadap suatu stimulus atau objek. Seseorang yang memiliki sikap yang postitif biasanya akan melakukan tindakan yang positif pula terhadap suatu objek, begitu pula sebaliknya jika seseorang memiliki sikap yang negatif maka tindakannya terhadap suatu objek akan negatif. (Notoatmodjo, 2011)

Menurut asumsi peneliti, responden yang memiliki sikap negatif yang melaksanaan universal precaution, hal ini disebabkan karena meskipun sikap perawat yang negatif yang kurang peduli terhadap pelaksanaan universal precaution namun mereka melihat adanya rekan kerja mereka yang selalu menerapkan universal precaution yang akhirnya membuat mereka termotivasi harus mengikuti rekan kerja tersebut dan juga adanya tuntutan dari atasan untuk melaksanakan universal precaution. Responden yang memiliki sikap negatif yang tidak melaksanaan universal precaution, disebabkan karena kepedulian perawat yang kurang terhadap pelaksanaan universal precaution dan perawat juga ada yang tidak terpengaruh dengan motivasi dan prestasi kerja dari teman sesama perawat yang lain dan juga kurang memperdulikan perintah atasannya sehingga mereka tidak acuh dan kurang peduli dengan pelaksanaan universal precaution yang harus dilakukan demi keselamatannya sendiri dan keselamatan pasiennya.

Responden yang memiliki sikap positif melaksanakan universal precaution, hal ini disebabkan karena responden yang memiliki sikap yang positif tentunya akan memiliki persepsi bahwa pelaksanakan universal precaution sangat penting dalam mencegah resiko tertular infeksi bagi diri sendiri dan bagi pasien sehingga mereka benar-benar menerapkan universal precaution yang benar dalam menjalankan tugasnya. Responden yang memiliki sikap positif yang tidak melaksanakan universal precaution, hal ini disebabkan keterbatasan waktu yang dimiliki oleh perawat sehingga perawat tidak memiliki waktu untuk selalu menerapkan tindakan universal precaution sesuai ketentuan dan mereka hanya melakukan hal-hal yang mereka anggap penting saja seperti mencuci tangan saja tanpa menggunakan alat pelindung diri.

Pada tabel 5 terlihat bahwa responden yang tidak melaksanakan universal precaution ditemukan pada perawat yang tidak pernah mendapatkan pelatihan yaitu 12 responden $(75,0 \%)$, dibandingkan perawat yang pernah mendapatkan pelatihan yaitu 3 responden $(18,8 \%)$, dengan hasil uji statistik nilai $\mathrm{p}=0,005$ (< 0,05) yang berarti $\mathrm{H}_{0}$ ditolak sehingga disimpulkan ada hubungan yang signifikan antara pelatihan dengan pelaksanaan universal precaution.

Hasil penelitian ini sama dengan hasil penelitian Krisnata (2016) bahwa pelatihan pencegahan dan pengendalian infeksi berhubungan dengan praktik universal precautions perawat ( $p$-value $=0,001)$.

Pelatihan terhadap penerapan kewaspadaan universal saat memberikan asuhan keperawatan terhadap pasien adalah bertujuan untuk meningkatkan kompetensi perawat yang meliputi determinan kemampuan dan ketrampilan agar dapat mencegah terjadinya penularan infeksi.

Menurut asumsi peneliti, responden yang tidak pernah mendapatkan pelatihan yang melaksanaan universal precaution, hal ini disebabkan karena meskipun tidak pernah mendapatkan pelatihan tentang pelaksanaan universal precaution namun mereka melihat adanya rekan kerja mereka yang selalu menerapkan universal precaution yang akhirnya membuat mereka termotivasi harus mengikuti rekan kerja tersebut dan juga adanya tuntutan dari atasan untuk melaksanakan universal precaution. Responden yang tidak pernah mendapatkan pelatihan yang tidak melaksanaan universal precaution, disebabkan karena 
keterbatasan ilmu dan pengetahuan yang mereka miliki dalam melaksanakan universal precaution dan juga tidak memperhatiakn teman sejawat dalam melaksanakan universal precaution sehingga mereka tidak melaksanakan universal precaution dengan baik.

Responden yang pernah mendapatkan pelatihan dan melaksanakan universal precaution, hal ini disebabkan karena responden yang pernah mendapatkan pelatihan tentunya akan mendapatkan ilmu dan pengetahuan bagaimana penting melaksanakan universal precaution dalam mencegah resiko tertular infeksi bagi diri sendiri dan bagi pasien sehingga mereka benar-benar menerapkan universal precaution dalam menjalankan tugas. Responden yang pernah mendapatkan pelatihan namun tidak melaksanakan universal precaution, hal ini disebabkan beban kerja dan keterbatasan waktu yang dimiliki oleh perawat sehingga perawat tidak memiliki waktu untuk selalu menerapkan tindakan universal precaution.

Tabel 6 terlihat bahwa responden yang tidak melaksanakan universal precaution dikarenakan sarana dan prasarana tidak mendukung yaitu 11 responden (84,6\%), dibandingkan sarana yang mendukung sebanyak 4 responden $(21,1 \%)$, dengan hasil uji statistik nilai $\mathrm{p}=0,001(<0,05)$ yang berarti $\mathrm{H}_{0}$ ditolak sehingga ada hubungan yang signifikan antara sarana dan prasarana dengan pelaksanaan universal precaution.

Hasil penelitian ini sama dengan hasil penelitian Krisnata (2016) bahwa ketersediaan sarana dan prasarana menjadi faktor yang berhubungan dengan pelaksanaan universal precaution ( $p$-value $=0,018)$.

Ketersediaan berarti kesiapan suatu sarana baik berupa tenaga, barang, modal, dan anggaran untuk dapat dipergunakan pada waktu yang telah ditentukan. Hal ini menunjukkan bahwa fasilitas yang tersedia harus dalam kondisi yang siap pakai, tidak rusak, tidak kadaluarsa, dan tidak kekurangan. Kemampuan yang mumpuni sekalipun, jika tidak ditunjang dengan fasilitas yang memadai tidak akan dapat meningkatkan efisiensi, efektivitas, dan produktifitas kerja. Demikian halnya dengan petugas kesehatan dalam melaksanakan universal precautions di tempat kerja diperlukan sarana dan fasilitas yang mumpuni (Krisnata, 2016).
Menurut asumsi peneliti, responden yang menyatakan sarana dan prasarana tidak mendukung namun tetap melaksanaan universal precaution, hal ini disebabkan karena meskipun ada sarana yang tidak memadai atau tidak mencukupi mereka tetap melaksanaan universal precaution sesuai dengan ketersediaan untuk tindakan yang akan dilakukan. Responden yang menyatakan sarana dan prasarana tidak mendukung dan tidak melaksanaan universal precaution, disebabkan karena mereka tidak mencari alternatif lain untuk menggantikan sarana yang kurang dengan yang lain sehingga mereka tidak melaksanaan universal precaution.

Responden yang menyatakan sarana dan prasarana mendukung dan melaksanakan universal precaution, hal ini disebabkan karena responden benar-benar menerapkan universal precaution dalam menjalankan tugas dengan sarana dan prasarana yang telah disediakan oleh rumah sakit. Responden yang menyatakan sarana dan prasarana mendukung namun tidak melaksanakan universal precaution, hal ini disebabkan kurang pedulinya perawat dalam menggunakan sarana dan prasarana yang ada dalam melaksanakan universal precaution.

\section{SIMPULAN}

Kesimpulan dari penelitian ini adalah terdapat hubungan yang signifikan antara tingkat pengetahuan, sikap, pelatihan, sarana dan prasarana dengan pelaksanaan Universal Precaution di Instalasi Gawat Darurat RSU Kerinci.

\section{DAFTAR PUSTAKA}

Angelia, M.L., Wagey, F,. Tumurang, M. (2016). Faktor-Faktor yang Berhubungan Dengan Penerapan Universal Precaution Oleh Perawat Di Ruang Rawat Inap Kebidanan Dan Kandungan RSUP. Prof. Dr. R. D. Kandou Manado. Tesis, Universitas Sam Ratulangi, Program Pascasarjana Universitas Sam Ratulangi.

Departemen Kesehatan, R.I. (2009). Pedoman Pencegahan Dan Pengendalian Infeksi Di Rumahsakit Dan Fasilitas Pelayanan Kesehatan Lainnya. Jakarta.: Departemen Kesehatan RI.

Duerink, O., Farida, H., Nagelkerke, N., et al. (2006). Preventing Nosocomial Infections: Improving Compliance With Standard 
Precautions In An Indonesian Teaching Hospital. Journal of Hospital Infection, 64, 36-43.

Efstathiou, G. P. (2011). Factors Influencing Nurses' Compliance with Standard Precautions to Avoid Occupational Exposure to Microorganism: A Focus Group Study. BMC Nursing , 10 (1), 1-12.

Gultom, A. U. (2016). Faktor-faktor yang Berhubungan Dengan Penerapan Kewaspadaan Universal (Universal Precaution) Oleh Perawat Di Ruang Rawat Inap Penyakit Dalam (IRINA C) RSUP. Prof Dr. R. D. Kandou Manado. Program Pascasarjana Universitas Sam Ratulangi.

Hermana, A. (2009). Faktor-Faktor yang Berhubungan dengan Terjadinya Luka Tusuk Jarum atau Benda Tajam Lainnya pada Perawat di Rumah Sakit Umum Daerah Kabupaten Cianjur. Depok: Universitas Indonesia.

Indriyani, Y. (2016). Analisis Implementasi Kesehatan Dan Keselamatan Kerja Di Rumah Sakit (K3RS) Menggunakan Metode PDCA (Plan-Do-Check-Act) Di RSUD Dr. Moewardi Surakarta. Surakarta: Universitas Muhammadiyah Surakarta.

Iswanti, T. (2017). Analisis Faktor yang Mempengaruhi Pelaksanaan Universal Precaution pada Pertolongan Persalinan Oleh Bidan Praktik Mandiri di Wilayah Kota Tangerang Selatan. diambil kembali dari http://digilib.unisayogya.ac.id/2454/

Kirkland, K. H. (2011). Nurses and Standard/Universal Precautions Analysis of Barriers Affecting Strict Compliance.
Washington: The Faculty of The School of Public Health and Health Services the George.

Krisnata, A. (2016). Faktor-Faktor yang Berhubungan dengan Praktik Universal Precautions pada Perawat dalam Upaya Pencegahan Risiko Healthcare Associated Infections (HAIs) di Ruang Rawat Inap RSUD Tugurejo Semarang. Semarang: Jurusan Ilmu Kesehatan Masyarakat Fakultas Ilmu Keolahragaan Universitas Negeri Semarang.

Luo, Y., He, G.P., Zhou, J.W., \& Ying, L. (2010). Factors Impacting Compliance with Standard Precautions in Nursing in China. International Journal of Infectious Disease, 14 (12), 106-114.

Notoatmodjo. (2011). Kesehatan Masyarakat Ilmu \& Seni. Jakarta: Rineka Cipta.

Nursalam. (2007). Konsep dan penerapan metodologi penelitian ilmu keperawatan. Jakarta: Salemba Medika.

Sahara, A. (2011). Faktor-Faktor Yang Berhubungan Dengan Kepatuhan Perawat Dan Bidan Dalam Penerapan Kewaspadaan Universal/Kewaspadaan Standar Di Rumah Sakit Palang Merah Indonesia Bogor Tahun 2011. Universitas Indonesia, Fakultas Kesehatan Masyarakat. Jakarta: Universitas Indonesia.

Syahrizal, I., Darwin, K., \& Fathra, A. (2015). Hubungan Pengetahuan Perawat tentang Universal Precautions dengan Penerapan Universal Precautions 7 pada Tindakan Pemasangan Infus. Riau: Universitas Riau. 